DOI: https://doi.org/10.47405/mjssh.v6i10.1098

\begin{tabular}{|c|c|}
\hline 4 & Malaysian Journal of Social Sciences and Humanities (MJSSH) \\
\hline $\begin{array}{l}\text { Malaysian Juoural of } \\
\text { Social ccciecces and }\end{array}$ & Volume 6, Issue 10, October 2021 \\
\hline (MJ-sSH) & e-ISSN : 2504-8562 \\
\hline & $\begin{array}{l}\text { Journal home page: } \\
\text { www.msocialsciences.com }\end{array}$ \\
\hline
\end{tabular}

\title{
Who Is a Native of Sabah? A Legal Analysis
}

\author{
Rafidah@Malissa Binti Salleh¹, Lenny James Matah¹, Ku Mohd Amir Aizat Ku Yusof1, \\ Hershan@Ray Herman' \\ 1Universiti Teknologi MARA Sabah Branch, Malaysia
}

Correspondence: Rafidah@Malissa Binti Salleh (rafidah632@uitm.edu.my)

\begin{abstract}
Article 161A of the Federal Constitution provides for the special position of natives of Sabah and Sarawak. Who are the natives of Sabah? There are legal definitions provided in the Federal Constitution, the State Constitution of Sabah and the Sabah Interpretation (Definition of Native) Ordinance 1952. However, each provision provides vague and unclear definitions for the term "native". This vague and inconsistent definition leads to so many problems faced by the natives of Sabah, both in economic and political aspects. Thus, this paper aims to analyse the relevant legal provisions concerning the definition of a native of Sabah and highlight possible solutions to the problems.
\end{abstract}

Keywords: definition, native, native law, State of Sabah

\section{Introduction}

Who is a native of Sabah? According to Ramy Bulan in one of her articles [1], she stated that the "native" identity issue is pertinent because of the political and economic implications that flow from it within the ambit of indigenous identity. In the State of Sabah, there is a suggestion to use "indigenous" rather than "native."[2] Is there any difference between the two terms? This paper intends to analyse the legal definitions for the term "native" and the issues that arise from the given meanings. Article $161 \mathrm{~A}(6)$ of the Malaysian Federal Constitution states that a native of Sabah refers to a person who is a citizen, the child or grandchild of a person of a race indigenous to Sabah, and was born whether on or after Malaysia Day or not, either in Sabah or to a father domiciled in Sabah at the time of the birth. The definition is similar to Article 41(10) of the Constitution of the State of Sabah.

Further reference needs to be made to another state law, the Sabah Interpretation (Definition of Native) Ordinance 1952.[3] Section 2(1) of the Ordinance defines the word "native" to include several categories of persons. The first category is persons whose parents are members of an "indigenous community".[4] The second category comprises Sabah residents who live as members of the native community and are descended from parents or ancestors, at least one of whom is native.[5] The third category refers to any person in Sabah and a member of the Suluk, Kagayan, Simonol, Sibutu or Ubian people or people indigenous to the State of Sarawak or Brunei.[6] The fourth category refers to any person who is resident in Sabah, and a member of a people indigenous to the Republic of Indonesia or the Sulu group of islands in the Philippine or the States of Malaya or Singapore, has lived as a member of a native community for five years; are of good character and are not subject to immigration control.[7] 
By reading the said provision, it is argued that the definitions given by these three legislations contradict each other, making the provision of laws as to the definition of "native" vague. For example, the list of races to be considered as indigenous to Sabah, as stated in Section 2(1)(c) of the Sabah Interpretation (Definition of Native) Ordinance 1952, is incomplete even to cover all ethnics and races in Sabah, which have been recognised as indigenous such as the Murut people.

\section{Definition of Native, Indigenous and Aboriginal}

The issue is whether the term "native", "indigenous" and "aboriginal" connote the same meaning? Or is there any difference between these terms?

The word "native" is an adjective. It is defined as relating to or describing someone's country or place of birth or being born in a particular country or place.[8] And most of the time, the word native is used interchangeably with the word aboriginal and indigenous. The Oxford English Dictionary defines a native as someone or something which is 'born or produced naturally in a land or region; native to that soil, region.'[9] Who then are the peoples generally considered an 'indigenous'?[10] The United Nations system has not adopted an official definition of "indigenous" due to the diversity of the world's indigenous peoples. Instead, a modern and inclusive understanding of "indigenous" has been developed and includes people who identify themselves, recognised and accepted by their community as indigenous, demonstrate historical continuity with pre-colonial and/or pre-settler societies, have strong links to territories and surrounding natural resources, distinct social, economic or political system, maintain distinct languages, cultures and beliefs, form non-dominant groups of society and resolve to keep and reproduce their ancestral environments and systems as distinctive peoples and communities.[11]

Although there is no universal definition of "indigenous people," the United Nations has adopted a working definition that identifies the common characteristics of indigenous people, including historical continuity since before pre-colonial societies, their non-dominant or marginalised situation, and the presence of customary, social and political institutions.[12] In 1982 the United Nations Working Group on Indigenous Populations (WGIP) accepted as a preliminary definition a formulation put forward by José R. Martínez-Cobo, Special Rapporteur on Discrimination against Indigenous Populations. Indigenous communities, peoples, and nations have a historical continuity with preinvasion and pre-colonial societies that developed on their territories, consider themselves distinct from other sectors of the societies now prevailing in those territories or parts of them. They form at present non-dominant sectors of society. They are determined to preserve, develop, and transmit to future generations their ancestral territories and their ethnic identity, as the basis of their continued existence as peoples, in accordance with their cultural patterns, social institutions and legal systems.[13]

In May 2016, the Fifteenth Session of the United Nations Permanent Forum on Indigenous Issues (UNPFII) affirmed that indigenous people (also termed aboriginal people, native people, or autochthonous people) are distinctive groups protected in international or national legislation as having a set of specific rights based on their linguistic and historical ties to a particular territory, prior to later settlement, development, and or occupation of a region. Erika Sarivaara et al.[14] argued in their article that significant international agreements defining the rights of indigenous peoples are the Convention no. 169 on Indigenous and Tribal Peoples by the International Labour Organization (ILO) from 1989 and the United Nations Declaration on the Rights of Indigenous Peoples by the General Assembly on 13 September 2007. The ILO No. 169 convention defines such peoples indigenous whose ancestors have lived in the area before the settlement or the formation of the modern state borders. The authors[15] further stated that indigeneity is defined differently in different countries. For example, New Zealand has a relatively liberal definition that accepts the multiformity of the Maori culture. The basis of definitions is also in bloodline or indigenous languages. This has led to a problem if a part of an indigenous people has been excluded from the indigenous status, and their identity has not been accepted. For the vital future of indigenous peoples, we see that an inclusive approach to the definition is needed. 
In Malaysia, it was estimated that the indigenous peoples of Malaysia represented about $13.8 \%$ of the population of 31,660,700 million in 2015.[16] The indigenous peoples of Peninsular Malaysia are collectively known as Orang Asli. The 18 Orang Asli subgroups within the Negrito (Semang), Senoi and Aborigen-Malay groups represent around 210,000 people or $0.7 \%$ of the population of Peninsular Malaysia.[17] In Sarawak, indigenous peoples are collectively known as natives (Dayak and/or Orang Ulu). They include the Iban, the Bidayuh, the Kenyah, the Kayan, the Kedayan, the Lunbawang, the Punan, the Bisayah, the Kelabit, the Berawan, the Kejaman, the Ukit, the Sekapan, the Melanau and the Penan, and the account for 1,932,600 people, or 70.5\% of the population of Sarawak.[18] In Sabah, the 39 different indigenous ethnic groups are known as natives or Anak Negeri and constitute about $2,233,100$ people or $58.6 \%$ of the population of Sabah. The main groups are the Dusun, Murut, Paitan and Bajau groups.[19]

Although the Malays are indigenous to Malaysia, they are not categorised as indigenous peoples because they constitute the majority and are political, economically and socially dominant.[20] Section 2 of the Aboriginal Peoples Act 1952 defines "aboriginal community" as the members of one aboriginal ethnic group living together in one place. And "aboriginal ethnic group" means a distinct tribal division of aborigines as characterised by culture, language or social organisation and includes any group which the State Authority may, by order, declare to be an aboriginal ethnic group. Further section 3(1) of the Aboriginal Peoples Act 1954378 defines the word 'aborigine' as follows:

Section 3(1) In this Act, an aborigine is -

a) Any person whose male parent is or was, a member of an aboriginal ethnic group, who speaks an aboriginal language and habitually follows an aboriginal way of life and aboriginal customs and beliefs, and includes a descendant through males of such persons;

b) any person of any race adopted when an infant by aborigines who have been brought up as an aborigine, habitually speaks an aboriginal language, habitually follows an aboriginal way of life and aboriginal customs and beliefs and is a member of an aboriginal community; or

c) the child of any union between an aboriginal female and a male of another race provided that the child habitually speaks an aboriginal language, habitually follows an aboriginal way of life and aboriginal customs and beliefs and remains a member of an aboriginal community.

The Aboriginal Peoples Act 1952 does not apply to Sabah and Sarawak. Thus, the word "native", which is the commonly used term to refer to the indigenous people in both states, is nowhere to be found in the statute. The term "aboriginal" shares a very similar dictionary definition with the word "indigenous". It can be used as an adjective generally referring to natives or a proper noun.[21] On a political level, however, it is argued that the term "aboriginal" or "aborigine" has gained a negative, derogatory implication due to the term's historical link with colonialism.[22] "Indigenous" is the expansive classification of communities claiming historical continuity and cultural affinity with societies native to their original territories. Aboriginal people, on the other hand, are a subclass encircling the different indigenous communities.[23] Therefore, it is concluded that the three terms discussed, namely "native", "indigenous", and "aboriginal", do not share the same meaning.

Within the scope of the paper, it is submitted that it is crucial to identify who is and can be considered as a native of Sabah. This is because native laws are only applicable to natives, and the native courts in the Sabah, have jurisdiction only to the natives. Since the colonial period, the meaning of "native" has been given and defined according to how the West sees the East, and not to determine the rights or entitlement of the natives.[24] For instance, in the Land Proclamation 1913, Proclamation 3 defines "native" as any aboriginal inhabitant of the Malays Archipelago and the children of such an inhabitant by any union with any native or alien, or any other Asiatic who may be or become entitled to rank as a native in accordance with rules laid down for the purpose.[25] Another shocking definition could be found in the Christian Marriage Ordinance 1919. The Ordinance defines "native" as a person not of European descent. 


\section{Definition of "Native" in the Federal Constitution}

The Federal Constitution does recognise these three categories of indigenous people.[26] Article 160(2) defines an "aborigine" merely as "an aborigine of the Malay Peninsula", commonly known as Orang Asli. The drafters of the Federal Constitution identified the indigenous people in Sabah and Sarawak as "natives" and preferred to name indigenous people in the peninsula as the "aborigines" or "Orang Asli.". Article 161A(6)(b)[27] of the Federal Constitution defines a "native" of Sabah. It states that for a person to be considered a native of Sabah, he must be;

i. a citizen of Malaysia;

ii. the child or grandchild of a person of a race indigenous to Sabah; and

iii. born either in Sabah or to a father domiciled in Sabah.

By looking at the provision, it is clearly shown that a native of Sabah must be a person who was born in Sabah or to a father domiciled in Sabah. The authors argue that the word "father" in Article 161A(6)(b) of the Federal Constitution reflects gender bias.[28] And therefore, it is submitted that it violates Article 8(1) and Article 8(2) of the Federal Constitution. Article 8(1) states that all persons are equal before the law and entitled to the equal protection of the law. There shall be no discrimination against citizens on the ground only of religion, race, descent, place of birth or gender in any law or in the appointment to any office or employment under a public authority or in the administration of any law relating to the acquisition, holding or disposition of property or the establishing or carrying on of any trade, business, profession, vocation or employment.

Shad Saleem Faruqi argues[29] that Article 8(2) of the Federal Constitution should not be seen as an overarching and overriding provision to limit the scope of the generic provisions of Article 8(1). The five prohibited grounds do not constitute a comprehensive or exhaustive list of banned criteria of classification. Shad Saleem Faruqi further commented that bias against women is also evident in citizenship laws, personal laws and the law relating to the natives of Sabah and Sarawak. Thus, this research finds it just and appropriate for the word "father" to be changed to "parent" to avoid any gender bias in determining who is a native of Sabah. By having such an amendment, the provision will be in line with Article 8(1) and Article 8(2) of the Federal Constitution of Malaysia.

\section{Definition of 'Native' in the Constitution of the State of Sabah}

The word "native" is defined in Article 41(10) of the Constitution of the State of Sabah. The said provision states that "native" means a person who is a citizen, is the child or grandchild or a person indigenous to the State and was born (whether on or after Malaysia Day or not) either in the State or to a father domiciled in the State at the time of the birth. Again, the word "father"' is used in Article 41(10)[30] of the constitution of the State of Sabah. Thus, this research submits that the provision is gender bias and contravenes Article 8(1)[31] and Article 8(2) of the Federal Constitution. Such provision must be amended to make it neutral and in line with the concept of equality before the law as enshrined in Article 8(1) and (2) of the Federal Constitution.

\section{Definition by the Interpretation (Definition of Native) Ordinance (Sabah Cap 64)}

The Interpretation (Definition of Native) Ordinance (Sabah Cap 64) is another important law that governs the definition of "native" in Sabah. To reiterate, Article $161 \mathrm{~A}(6)(\mathrm{b})$ of the Federal Constitution states,

"Native" means...

(b) in relation to Sabah, a person who is a citizen is the child or grandchild of a person of a race indigenous to Sabah and was born (whether on or after Malaysia Day or not) either in Sabah or to a father domiciled in Sabah at the time of the birth. 
The term "of races indigenous to Sabah" is nowhere defined by the Federal Constitution. Therefore, it is crucial to refer to the state legislation, namely the Interpretation (Definition of Native) Ordinance. Section 2(1) of the Interpretation (Definition of Native) Ordinance 1952 defines,

The term "Native" whenever the word occurs in any written law unless expressly otherwise enacted therein, as meaning either -

a) any person both of whose parents are or were members of a people indigenous to the Sabah; or

b) any person ordinarily resident in Sabah and being and living as a member of a native community, one at least of whose parents or ancestors is or was a native within the meaning of paragraph (a) hereof; or

c) any person who is ordinarily resident in Sabah is a member of the Suluk, Kagayan, Simonol, Sibutu or Ubian people or of a people indigenous to the State of Sarawak or the State of Brunei, has lived as and been a member of a native community for a continuous period of three years preceding the date of his claim to be a native, has borne a good character throughout that period, and whose stay in Sabah is not limited under any of the provisions of the Immigration Act, 1959/63: or

d) any person who is ordinarily resident in Sabah, is a member of a people indigenous to the Republic of Indonesia or the Sulu group of islands in the Philippine Archipelago or the States of Malaya or the Republic of Singapore, has lived as and been a member of a native community for a continuous period of five years immediately preceding the date of his claim to be a native, has borne a good character throughout that period and whose stay in Sabah is not limited under any of the provisions of the Immigration Act, 1959/63.

Based on the said legal provision, natives of Sabah are defined as those whose parents are Sabah Orang Asli (Sabah Origin or natives), anyone living as a member of the native community where one of his parents or ancestors are natives. By referring to section 2(1)(a), the term "people indigenous" to Sabah are used. And the same problem occurs, that this term is nowhere to be defined in the Ordinance. Hence, this makes the definition of a native of Sabah vague and unclear. Who are people indigenous to Sabah?

Further, according to section 2(3) of the same Ordinance, none of the above is valid unless "an appropriate declaration made by a Native Court under section 3". Section 2(3) of the Interpretation (Definition of Native) Ordinance 1952 indicates, No claim by any person to be a native by virtue of the provisions of paragraphs (b), (c) and (d) of subsection (1) shall be recognised as valid unless supported by an appropriate declaration made by a Native Court under section 3 .

It can be concluded that only those who fall under section 2(1)(a) will get the native status automatically. The rest[32] will have to apply to the Native Court before they can be recognised as natives of Sabah. The requirement of Native Certificate or Sijil Anak Negeri only exists in the Interpretation (Definition of Native) Ordinance 1952, but there is no such requirement stated in the Federal Constitution. This research also finds that the terms "native" and "indigenous" have been used interchangeably in the state enactments. Therefore, it is presumed that both share similar meanings in the context of the State of Sabah.

Another emerging issue that this research finds is that section 2(1)[33] of the Interpretation (Definition of Native) Ordinance states that one does not have to be a Malaysian citizen to be declared a Sabah native. There is no requirement that one needs to be a citizen (of this country) to be a native in the Ordinance. The research concludes that this will definitely affect the rights of local natives, especially in matters involving ownership of native land title in the State. Therefore, this research humbly submits that a pre-condition of citizenship of Malaysia must be fulfilled before one could be deemed as a native and governed by the native law.

As of today, the only ethnic groups that are clearly defined in the Ordinance are members of the Suluk, Kagayan, Simonol, Sibutu or Ubian people, the people indigenous to the State of Sarawak or the State of Brunei. Section 2(d) of the Ordinance extends to the people who are members of a people indigenous to the Republic of Indonesia or the Sulu group of islands in the Philippine Archipelago or the states of Malaya or the Republic of Singapore. There is no mention of the 44 ethnic groups[34] that 
made up the people in Sabah in this Ordinance. Therefore, this research finds out that until the definition of native is made clear and accurate, the problem relating to who is native of Sabah will continue to exist.

In the case of Liew Siew Yin v. District Officer, Jesselton[35] the claim to be classified as a native was refused on the ground that the plaintiff did not live as a member of a native community. He was married according to Chinese custom, had given his children Chinese names and had never paid the poll tax. He lived in a mixed community, part native and part Chinese. While refusing his application, the court said if he elected to take up residence in a native community and renew his application, it would receive favourable consideration. The interesting point about this decision is that the court held that the definition of native in the Interpretation (Definition of Native) Ordinance refers to both ways of life and descent. On these criteria, the applicant was held not to qualify.[36]

In a later case, Ong Seng Kee v. District Officer, Inanam [37] , the same two criteria were considered. Still, here the application succeeded mainly because the local native officials gave evidence that, so far as they were concerned, the applicant had always been considered locally to be a member of the native community. Religion does not appear to be a criterion in the determination of the status of the native.[38] The Native Court, in the case of Haji Mohd Nasaruddin bin Abdullah [39] ruled that religion was not an ingredient required by the Ordinance.

Interestingly, even a person from the peninsula can become a native as long as he fulfils the requirement stated in the Ordinance. In the case of Datuk Syed Kechik bin Syed Mohd v Government of Malaysia \& Anor[40] , the applicant, a Malaysian citizen by operation of law, was assigned to Sabah in 1965 as a political secretary. In 1967, he applied for and was granted an entry permit to remain permanently in the State pursuant to section 10 of the Immigration Act 1959/63. He later applied to the Native Court of Kota Kinabalu for a declaration of his status as "Anak Negeri" Sabah and was admitted to that status.[41] The Federal Court held that he rightly was a person who belonged to the State, and that position was reinforced by the declaration of the Native Court that he was a native. Lee Hun Hoe CJ (Borneo) at 108 said:
"The significance of the declaration made by the Native Court that the appellant is an 'anak Negeri of Sabah should not be overlooked. Such a declaration would only be made if the applicant were able to satisfy the court of his being a member of a people indigenous in Malaysia, his residence in Sabah, his living as a member of a native community for a continuous period of five years immediately prior to his claim and of his good character. Furthermore, another consideration was that his stay was not limited to the Immigration Ordinance. Section 3(2) of the Ordinance makes clear that the Native Court shall have exclusive jurisdiction to entertain and determine such application and to make such a declaration. Section 3(3) of the Ordinance provides that there may be an appeal against such declaratio...As there has been no appeal, the declaration is binding for section 3(4) of Cap 94 which states that such declaration made shall be conclusive evidence for all purposes in respect of the matter or matters to which it relates. The implication is that the appellant is considered a native in Sabah and is entitled to be treated as such under the immigration law. As a native, he belongs to Sabah."

In the case of Masbaka Bin Hj Hassan \& Ors v. The Government of Malaysia \& Ors,[42] the High Court held that neither the Interpretation (Definition of Native) Ordinance nor the Constitution of Sabah defines what is meant by "people indigenous to Sabah". In this case, the plaintiffs claimed to be natives of Sabah by ethnic origins and brought an action against the defendants, who had demolished their houses on the State land. The plaintiffs sought a declaration that they have a right to occupy and use the State land under customary rights, and therefore, the demolition of their houses by the defendants was unlawful. The court established that none of the plaintiffs testified that both of their parents are or were members of a people indigenous to Sabah. The court held that because a person is a Kadazan or a Bugis that therefore both of his parents must be Kadazan or Bugis and belong to a race or people indigenous to Sabah, bearing in mind that mixed marriages are common and normal in 
Sabah. Thus, it is not sufficient under paragraph (a) of Section 2(1) of the Interpretation (Definition of Native) Ordinance for a person to be defined as native if only a parent is or was a member of a people of indigenous to Sabah. The burden is on the plaintiffs to prove that they are natives of Sabah in accordance with the laws of Sabah. Section 2(3) of the Ordinance provides that no claim by any person to be a native by virtue of the provisions of paragraphs (b), (c) and (d) of subsection (1) shall be recognised as valid unless supported by an appropriate declaration made by a Native Court under section 3 of the Ordinance. The court held that none of the plaintiffs had exhibited any such declaration or certificate made by a Native Court in accordance with section 3, and therefore, none of the plaintiffs has proved that they are natives as defined in section 2(1)(b), (c) and (d) of the Ordinance.

In the case of Hon Chung Lip v. Kwan Ngen Wah \& Ors,[43] the appeal case involved the issues of a native of Sabah and Native Title land. At the hearing before the court below, the respondents questioned the status of the appellant as a native. The judicial commissioner found that the appellant had obtained the native certificate illegally and that the appellant was not a native. According to this finding and premised on the law which expressly prohibited native land dealings between natives and non-natives, the JC held that the SPAs executed between the appellant and the applicants were void ab initio. This was the appellant's appeal against that decision.

On appeal, this court was of the view that the JC had erred in refusing to accept the appellant's native certificate as prima facie evidence of the appellant's status as a native. In any case, the proper forum to raise the issue of the validity of the appellant's native certificate was before the native court and not before the JC. Thus, based on the evidence before, this court found that the appellant was a native of Sabah. The court referred to section 3(2) of the Interpretation (Definition of Native) Ordinance (Cap 64) which provides that the Native Court shall have exclusive jurisdiction to entertain and determine any application made to it by a person for a declaration that such a person falls within one of the paras (a)-(d) of the said provision.

By reading the cases, it can be concluded that the root of the problem is the lack of a proper or accurate definition of a native of Sabah. It is submitted that by referring to Article 161A(6)(b) of the Federal Constitution, Article 41(10) of the Constitution of the State of Sabah and Section 2 of the Interpretation (Definition of Native) Ordinance, there are a few crucial points to be observed. Firstly, the wordings in Article 161A(6)(b) of the Federal Constitution and Article 41(10) of the State Constitution are worded substantially the same. Between the Federal Constitution and the Interpretation (Definition of Native) Ordinance, a person may be qualified as a native under the said Ordinance but may not be qualified as a native under the Federal Constitutions and vice versa. Further, under the Federal Constitution, a person must be a Malaysian citizen to be qualified as a native, but not under the said Ordinance. There is a requirement to obtain an appropriate declaration, i.e. Native Certificate (Sijil Anak Negeri) but no such requirement under the Federal Constitution. A person can claim to be a native if one of the parents or ancestors is or was a native within the meaning of section 2(1)(a) of the Ordinance, that is, a person indigenous to Sabah. In both the Federal Constitution and the State Constitution, the word "grandchild" is used. Thus, it means the laws may only allow a person to trace his native root up to his grandparents only.

The Ordinance allows people from outside Sabah, for example, people indigenous to Indonesia or the Sulu Group of Islands in the Philippine Archipelago or the States of Malaya or Singapore or Sarawak or Brunei who satisfy specific requirements to become "natives." Meanwhile, the Federal Constitution and the State Constitution only allow people who are members of or are descended from a people indigenous to the countries, states or places outside Sabah, as mentioned above.

The authors also address conflicting provisions between the Federal Constitution, the State Constitution and the Ordinance. In the event of a conflict between the State Constitution and the Ordinance, it is safe to say that the State Constitution prevails. And between the State Constitution and the Federal Constitution, one may argue that the Federal Constitution prevails. However, in the context of the State of Sabah, it may not be so. It is submitted that based on the Eighth Schedule[44] of the 
Federal Constitution, the "definition of native" is not listed in the schedule. Therefore, it is argued that on this matter, the State Constitution may prevail.

[1] Bulan, R. (1998). Indigenous identity and the law: Who is a native? Journal of Malaysian and Comparative Law, 25, 127. Lembah Pantai, KL: University of Malaya.

[2] 'Indigenous' or 'native', Sabah to decide" by Olivia Miwil on 18.01.2019 retrieved from https://www.nst.com.my/news/nation/2019/01/452040/indigenous-or-native-sabah-decide

[3] Prof Dr Shad Saleem Faruqi (2008) Document of Destiny, The Constitution of the Federation of Malaysia, Kuala Lumpur: Star Publications (M'sia) Bhd Kuala Lumpur, p. 705

[4] Section 2(1)(a) of the Sabah Interpretation (Definition of Native) Ordinance 1952

[5] Section 2(1)(b) of the Sabah Interpretation (Definition of Native) Ordinance 1952

[6] Section 2(1)(c) of the Sabah Interpretation (Definition of Native) Ordinance 1952

[7] Section 2(1)(d) of the Sabah Interpretation (Definition of Native) Ordinance 1952

[8] https://dictionary.cambridge.org/dictionary/english/native

[9] https://www.nzcpr.com/who-is-indigenous

[10] Lewis, D. M. (1997). Indigenous Peoples, Ethnic Groups and the State (p. 9). Pearson.

[11] Ibid

[12] Martinez Cobo Study, E/CN.4/Sub.2/1986/7/Add.4, para 379

[13] https://www.un.org/development/desa/indigenouspeoples/about-us.html

[14] Sarivaara, E., Maatta, K., \& Uusiautti, S. (2013, December). "who is indigenous? definitions of indigeneity”. European Scientific Journal ,1 ISSN: 1857 - 7881 (Print) e - ISSN 1857- 7431. Retrieved from eujournal.org/index.php/esj/article/viewFile/2317/2190.

[15] Ibid

[16] http://law.um.edu.my/docs/librariesprovider6/event-seminar/clpil-2019-02-21/3-indigenous-

identity-and-the- constitution---shad-saleem-faruqi.pdf?sfvrsn=2

[17] https://iwgia.org/en/malaysia

[18] Ibid

[19] Ibid

[20] https://iwgia.org/en/malaysia

[21] www.differencebetween.net/miscellaneous/difference-between-aboriginal-and-indigenous/

[22] Ibid

[23] Paul Porodong, "Definitional Challenges of Indigenous Identity of Sabah" presentation slides Retrieved from law.um.edu.my/docs/librariesprovider6/event-seminar/clpil-2019-02-21/5-nativeidentity-in-sabah--- paul-porodong.pdf?sfvrsn=2

[24] Ibid

[25] Ibid

[26] Yunus, H. M. (2018). Protection of marginalised minorities under the constitution. 1 LNS(A) lx. Retrieved from http://www.cljlaw.com.ezaccess.library.uitm.edu.my/Members/DisplayArticle. aspx?ArticleId=13225 $1718 \&$ SearchId=2maralib1\#b6 on 08.0.2018

[27] Article $161 \mathrm{~A}(6)(\mathrm{b})$ of the Federal Constitution states, in this Article, "Native" means... (b) in relation to Sabah, a person who is a citizen, is the child or grandchild of a person of a race indigenous to Sabah, and was born (whether on or after Malaysia Day or not) either in Sabah or to a father domiciled in Sabah at the time of the birth.

[28] Article 8(2) of Federal Constitution

[29] Faruqi, S. S. (2008). Document of Destiny, The Constitution of the Federation of Malaysia (p. 266). Selangor:

[30] The same word has been used in Article $161 \mathrm{~A}(6)(\mathrm{b})$ of the Federal Constitution of Malaysia. The research finds this as gender bias and violating the concept of equality before the law.

[31] Article 8(1) states, 'All persons are equal before the law and entitled to the equal protection of the law'

[32] Section 2(1)(b), (c) and (d) of the Interpretation (Definition of Native) Ordinance

[33] Section 2 (1) states, Wherever the word "native", used as a substantive, occurs in any written law in force at the commencement of this Ordinance, other than the Ordinances set out in the Schedule to 
this Ordinance, or in any written law coming into force after the commencement of this Ordinance, unless expressly otherwise enacted therein, it shall mean either -

(a) any person both of whose parents are or were members of a people indigenous to Sabah; or

(b) any person ordinarily resident in Sabah and being and living as a member of a native community, one at least of whose parents or ancestors is or was a native within the meaning of paragraph (a) hereof; or

(c) any person who is ordinarily resident in Sabah, is a member of the Suluk, Kagayan, Simonol, Sibutu or Ubian people or of a people indigenous to the State of Sarawak or the State of Brunei, has lived as and been a member of a native community for a continuous period of three years preceding the date of his claim to be a native, has borne a good character throughout that period and whose stay in Sabah is not limited under any of the provisions of the Immigration Act, 1959/63 [Act 155.]:

Provided that if one of such person's parents is or was a member of any such people and either lives or if deceased is buried or reputed to be buried in Sabah, then the qualifying period shall be reduced to two years; or

(d) any person who is ordinarily resident in Sabah, is a member of a people indigenous to the Republic of Indonesia or the Sulu group of islands in the Philippine Archipelago or the States of Malaya or the Republic of Singapore, has lived as and been a member of a native community for a continuous period of five years immediately preceding the date of his claim to be a native, has borne a good character throughout that period and whose stay in Sabah is not limited under any of the provisions of the Immigration Act, 1959/63 [Act 155.].

[34] Lampiran A. Senarai Suku Kaum Anak Negeri Sabah. This document is obtained from Department of Native Affairs, Kota Kinabalu, Sabah.

[35] N.C.A. No. 2 of 1959

[36] Hooker, M. B. (1980). Native Law in Sabah and Sarawak (p. 69). Malayan Law Journal Pte Ltd.

[37] N.C.A No. 28 of 1959

[38] Wu Min Aun. (1990). The Malaysian legal system (2nd ed., p. 185). Kuala Lumpur: Longman

[39] Case No 173/75, Kota Kinabalu Native Court

[40] [1979] 2 MLJ 101

[41] Ibid 38

[42] [2010] MLJU 1632

[43] [2012] 5 MLJ 356

[44] Eight Schedule of the Federal Constitution: Provisions to be inserted in the State Constutition 